\title{
Astrology in Mother-Tantric Literature
}

\section{Tsunehiko SUGIKI}

1. Introduction In spite of the fact that not a little information on astrology or fortunetelling is given in the works of Mather-Tantric literature, few studies have been conducted. This paper is intended as a comparative study of the system of astrology in accordance with the time of birth in Vajradalkatantra (=VD) chap. 10 and Catuspithatantra $(=\mathrm{CP})$ chap. $1-1^{2}$. Since descriptions of VD as well as CP are sometimes ambiguous, our understanding of their system is mainly based on Bhavabatta's commentaries on VD and $\mathrm{CP}^{3)}$.

2. Outline of the system Table 1 represents twelve divisions of a day mentioned in VD. Twelve divisions of time i.e. rohita, mohitā, bhadra and so on function as a base unit for astrology. These twelve divisions have the dawn as their starting point and are arranged in the order of east, south, west and north. They are related to vowels, sixty ghatis which constitute one day and night, the signs of the zodiac (rāsi i) and stars (nakșatra).

In comparing it with the system of $\mathrm{CP}$, there are three points which interests us : (i) In CP, the eleventh division is called svapna and the twelfth one is named käma. Bhavabatta explains, for the sake of coherence between VD and CP, that svapnika of VD means svapna and bhuvaneśvara of VD is equivalent to käma. $S$ vapnik $\bar{a}$ is thought to be a distorted word of svapnakāma (=svapna and kāma). The distortion could be explained as follows: At some time the 'ma' of 'svapnakāma' was omitted by accident, and then the 'svapnaka' was changed to 'svapnik $\vec{a}$. As a result, 'bhuvaneśvara' which was originally a general term for twelve divisions in CP became the name of the twelfth division in VD. (ii) Sixty ghatis are unevenly distributed, which means that the span of each division is not uniform. This is also the case with CP. (iii) In CP, twelve divesions of time together with their corresponding elements such as vowels, ghatis and so on are arranged in anticlockwise 
direction $^{4)}$. On the other hand, in VD they are arranged in clockwise direction as shown in Table l. When we focus on the signs of the zodiac and stars, CP's manner is considered to be popular as the system of astrology. (iv) No role of the planets is concretely explained. If the planets took an indispensable part of the system of VD and CP, more descriptions of their roles would have been given. As the system of Varāhamihira shows, planets generally play an important role in horoscope. Hence, systems of VD and CP may not be regarded as that of horoscope.

TABLE 1

\begin{tabular}{|c|c|c|c|c|c|c|}
\hline dawn & east & rohitā & A & 3ghați & meșa & aśvinī, bharanīi, kṛttikā $1 / 4$ \\
\hline & \multirow{5}{*}{ south } & mohitā & $\overline{\mathrm{A}}$ & 4ghați & vrșa & kụttikā 3/4, rohiṇī, mṛgaśīrșa $2 / 4$ \\
\hline & & bhadra & I & 5ghați & mithuna & mṛgaśīsṣa $2 / 4$, ārdrā, punarvasu $3 / 4$ \\
\hline & & vrṣabha & $\overline{\mathrm{I}}$ & 5ghați & karkața & punarvasu $1 / 4$, pușya, āśleșā \\
\hline & & kūrma & $\mathrm{U}$ & 4ghați & siṃha & maghā, pūrvaphālgunī, uttaraphālgunīl/4 \\
\hline & & makara & $\overline{\mathrm{U}}$ & 3ghați & kanyā & uttaraphālgunī, hasta, citrā $2 / 4$ \\
\hline & \multirow[t]{2}{*}{ west } & raṇ̣āā & $\mathrm{E}$ & 5ghati & tulā & citrā $2 / 4$, svāti, viśākhā $3 / 4$ \\
\hline & & mikira & AI & 7ghați & vriścika & viśākhā $1 / 4$, anurāọhā, jyeșthā \\
\hline & \multirow{4}{*}{ north } & bhidrika & $\mathrm{O}$ & 6ghați & dhanus & mūla, pūrvāșāḍhā, uttarāṣāụhā $2 / 4$ \\
\hline & & vyākuli & $\mathrm{AU}$ & 6ghați & mrga & uttarāṣāḍdhā $3 / 4$, śravaṇa, dhaniș̣thā $2 / 4$ \\
\hline & & svapnika $^{i)}$ & AM & 7ghați & kumbha & dhanișthā $2 / 4$, śatabhișaj, pūrvabhādrapadā $3 / 4$ \\
\hline & & bhuvaneśvara $^{i i)}$ & $\mathrm{AH}$ & 5ghați & mīna & pūrvabhādrapadā $1 / 4$, uttarabhādrapadā, revatī \\
\hline
\end{tabular}

i) = svapna

ii) = kāma

3. Application of twelve divisions to months and days VD and $\mathrm{CP}$ explain twelve divisions of a year and a month on the basis of the system of twelve divisions of time. Table 2 summerizes the ideas in VD. As the month goes by, each of twelve divisions by which the days (lst day to 12th day) are demarcated shifts one by one. For the purpose of computing, the Pausa is regarded as the starting month. This idea seems peculiar to this system since it is usual to start from the Caitra.

TABLE 2

\begin{tabular}{|c|l|c|c|c|c|}
\hline & $\begin{array}{c}\text { lst month } \\
=\text { rohitā }\end{array}$ & $\begin{array}{c}\text { 2nd month } \\
=\text { bhuvaneśvara }\end{array}$ & $\begin{array}{c}\text { 3rd month } \\
=\text { svapnikā }\end{array}$ & $\begin{array}{c}\cdots \\
\cdots\end{array}$ & $\begin{array}{c}12 \text { th month } \\
=\text { mohitā }\end{array}$ \\
\hline lst day & rohitā & bhuvaneśvara & svapnikā & $\cdots$ & mohitā \\
\hline
\end{tabular}




\begin{tabular}{|c|c|c|c|c|c|}
\hline 2nd day & mohitā & rohitā & bhuvaneśvara & $\cdots$ & bhadra \\
\hline 3rd day & bhadra & mohitā & rohitā & $\cdots$ & vṛșabha \\
\hline 4th day & vrṣabha & bhadra & mohitā & $\cdots$ & kūrma \\
\hline 5 th day & kūrma & vrṣabha & bhadra & $\cdots$ & makara \\
\hline 6 th day & makara & kūrma & vṛșabha & $\cdots$ & raṇ̣āā \\
\hline 7th day & ranḍā & makara & kūrma & $\cdots$ & mikira \\
\hline 8 th day & mikira & raṇ̣āa & makara & $\cdots$ & bhidrika \\
\hline 9 th day & bhidrika & mikira & raṇụā & $\cdots$ & vyākuli \\
\hline 10th day & vyākuli & bhidrika & mikira & $\cdots$ & svapnikā \\
\hline 11th day & svapnikā & vyākuli & bhidrika & $\cdots$ & bhuvaneśvara \\
\hline 12th day & bhuvaneśvara & svapnikā & vyākuli & $\cdots$ & rohitā \\
\hline
\end{tabular}

In comparing the system of VD with that of CP, two differences are found : (i) In VD, twelve divisions are attributed to days in ordinary order, while to months they are attributed in reverse order. On the other hand, the ordinary order is accepted to the months as well as the days in CP. (ii) VD insists that when the thirteenth day, fourteenth day and fifteenth day are requested, divisions distributed to the third day, fourth day and fifth day ate again attributed to them. This explanation is not given in $\mathrm{CP}$.

4. Fortunetelling - time of birth and time of death VD and CP narrates the personality and fortune (future occupation and the time of death) of a person according to the divisions corresponding to the time of birth of the person. The instructions are the same in both their systems except certain points. One of the points is the relation between the time of birth and that of death. Table 3 shows the relations in the system of VD. The table should be read in this way: A person born at the time of rohita is to die at the time of bhuvaneśvara.

TABLE 3

\begin{tabular}{ll|ll|ll} 
Birth & : Death & Birth & : Death & Birth & : Death \\
\hline rohitā & $:$ bhuvaneśvara & bhuvaneśvara & $:$ svapnikā & svapnikā & : vyākuli \\
vyākuli & $:$ bhidrika & bhidrika & $:$ mikira & mikira & : raṇḍā \\
raṇḍ̄ & $:$ makara & makara & $:$ kūrma & kūrma & : vṛṣabha \\
vṛṣabha & $:$ bhadra & bhadra & $:$ mohitā & mohitā & : rohitā
\end{tabular}


What should be noted here is that the division of birth and that of death adjoin each other in reverse order. This is said to be due to the theoretical manipulation by VD. However, this attempt is not observed in CP. In other words, CP does not designate a particular division for death-time.

5. Conclusion From the above investigation, we may draw the following conclusions: (i) The system of VD and that of CP can be regarded as being in close relation with each other in that both assert twelve divisions of time as a base unit for astrology. (ii) Since the planets do not play an important role in the system of VD and CP, their system should be distinguished from that of horoscope as is seen in the system of Varāhamihira in which the planets are indespensable elements. (iii) From the matter of a distortion of svapnakāma, it is obvious that CP's system was composed earlier than VD's. (iv) The order of arrangement of twelve divisions of time in $\mathrm{CP}$ is inverted in some phases in the case of VD. From the fact that VD belongs to the Yoginitantra-movement which prefers the inverted order, it can be inferred that VD changed the order of arrangement prescribed in $\mathrm{CP}$, in accordance with the general tendency of the Yoginitantra literature.

* I would like to thank Prof. Eino, Prof. Mori, Prof. Saito, Prof. Takashima, Mr. Tanaka and Prof. Yano for their valuable comments on the previous draft of this paper.

1) Sanskrit Ms. Culcatta Śastri 72/ Tokyo Matsunami 343.

2) Sanskrit Ms. Cambridge Add. 1704/ Kathumandu Reel. 138/10.

3) Śrivajradākanāmamahātantrarājasya viṿ̛ti, Tib. Ota 2131. Śrīcatuṣpițhatantrarājasya tịkāsmṛtinibandhanāma, Tib. Ota 2478.

4) Connection of twelve divisions of time with the vowels, signs of the zodiac and stars is not clear in $\mathrm{CP}$ itself.

〈Key Words〉 astrology, fortunetelling, Vajradākatantra, Catuspịthatantra, Bhavabaț̣

(Part-time lecturer, Musashino Women's University, Ph.D) 